\title{
整形外科の疼痛性疾患に対する漢方治療
}

\author{
福嶋 裕造 ${ }^{\mathrm{a}}$ 藤田 良介 $\mathrm{b}$ 上野 力敏 $\mathrm{c}$ \\ 山下 和彦 $\mathrm{d}$ 内海 康生 $\mathrm{e}$ 清水 知已 $\mathrm{f}$ \\ 戸田 稔子 $\mathrm{g}$ 大森あさみ $\mathrm{h}$ \\ a 福嶋整形外科医院，鳥取， =682-0024 倉吉市伊木262-2 \\ b 鳥取市立病院総合診療科, 鳥取, T 680-8501 鳥取市的場 1-1 \\ 上野医院，鳥取， = 682-0804 倉吉市東昭和町38 \\ 三条山下内科医院，香川， ₹761-8072 高松市三条町504-1 \\ 内海皮フ科医院，島根， $\bar{\top} 690-0002$ 松江市大正町 456-7 \\ しみず内科クリニック，島根，テ690-0862 松江市比津が丘2丁目 2-14 \\ 松江生協病院女性診療科, 島根, $\overline{\mathrm{T}} 690-8522$ 松江市西津田8丁目8-8 \\ 石見クリニック，島根， † 698-0024 益田市駅前町7-1
}

\section{Kampo Medicine for the Treatment of Pain Due to Orthopedic Disorders}

\author{
Yuzo FUKUSHIMA $^{\mathrm{a}}$ Ryousuke FUJITA ${ }^{\mathrm{b}}$ Rikitoshi UENO ${ }^{\mathrm{c}}$ \\ Kazuhiko YAMASHITA $^{\mathrm{d}}$ Yasuo UTSUMI $^{\mathrm{e}}$ Tomomi SHIMIZU $^{\mathrm{f}}$ \\ Toshiko TODA $^{\mathrm{g}} \quad$ Asami OHMORI $^{\mathrm{h}}$
}

a Fukushima Orthopedic Clinic, 262-2 Igi, Kurayoshishi, Tottori 682-0024, Japan

b Department of General Medicine, Tottori Municipal Hospital, 1-1 Matoba, Tottorishi, Tottori 680-8501, Japan

Ueno Clinic, 38 Higashishowamachi, Kurayoshishi, Tottori 682-0804, Japan

d Sanjo Yamashita Internal Medical Clinic, 501-1 Sanjocho, Takamatsushi, Kagawa 761-8072, Japan

Utsumi Clinic of Dermatology, 456-7 Taichomachi, Matsueshi, Shimane 690-0002, Japan

Shimizu Internal Medical Clinic, 2-2-14 Hizugaoka, Matsueshi, Shinmane 690-0562, Japan

g Department of Gynecology, Matsue Cooperative Society Clinic, 8-8-8 Nishitsuda, Matsueshi, Shimane 690-8522, Japan

h Iwami Clinic, 7-1 Ekimaecho, Masudashi, Shimane 698-0024, Japan

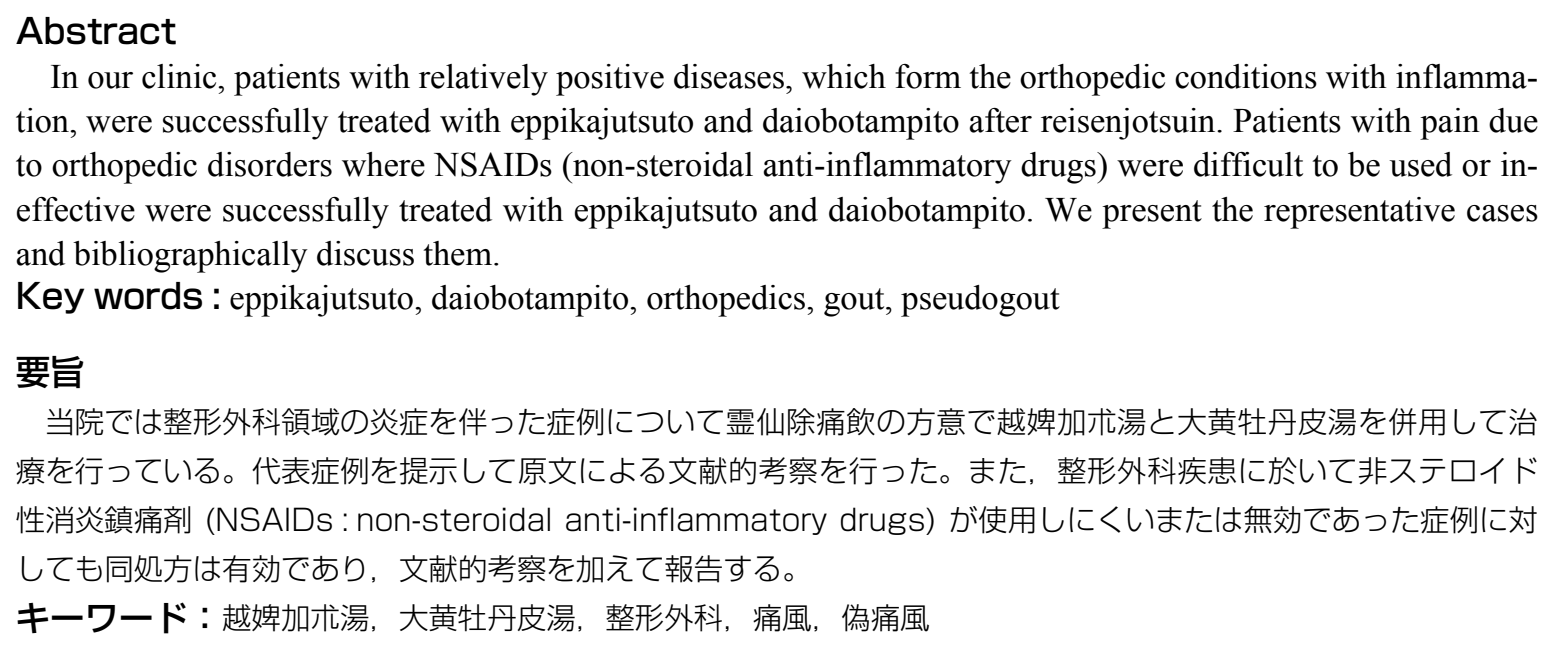

In our clinic, patients with relatively positive diseases, which form the orthopedic conditions with inflammation, were successfully treated with eppikajutsuto and daiobotampito after reisenjotsuin. Patients with pain due to orthopedic disorders where NSAIDs (non-steroidal anti-inflammatory drugs) were difficult to be used or ineffective were successfully treated with eppikajutsuto and daiobotampito. We present the representative cases and bibliographically discuss them.

Key words : eppikajutsuto, daiobotampito, orthopedics, gout, pseudogout

要旨

当院では整形外科領域の炎症を伴つた症例について霊仙除痛飲の方意で越婢加术湯と大黄牡丹皮湯を併用して治 療を行っている。代表症例を提示して原文による文献的考察を行った。また, 整形外科疾患に於いて非ステロイド 性消炎鎮痛剂 (NSAIDs : non-steroidal anti-inflammatory drugs) が使用しにくいまたは無効であった症例に対 しても同処方は有効であり，文献的考察を加えて報告する。 キーワード : 越婢加术湯, 大黄牡丹皮湯, 整形外科, 痛風, 偽痛風

\section{緒言}

当院では整形外科領域の炎症を伴った疼痛性疾患 に対してエキス製剤の越婢加术湯と大黄牡丹皮湯の 併用による多数の治療経験がある11。今回, 代表症 例を提示し同処方の文献的考察を行った。また様々
な理由によって NSAIDs が使用困難または無効例に 対して同処方が有効であり, 代表症例を提示して考 察を行った。

\section{症例 $1 ：($ 漢方治療有効例) \\ 患 者：88歳, 女性。}


主 訴: 左足関節痛

既往歴：近医にて軽度の認知症, 脂質異常症でド ネペジル塩酸塩, プラバスタチンナトリウムを内服 中であった。

現病歴：左足関節痛があり同日，当院受診となっ た。同疾患にて当院受診前に近医受診, 内服等の医 療行為は行っていなかった。

初診時医学的所見：身長 $140.0 \mathrm{~cm}$, 体重 $49.0 \mathrm{~kg}$, 体温36.8度, 血圧136/71 mmHg, 脈拍84回/分であっ た。左足関節痛在り, 同部位に腫脹あり。血液検查, 免疫学的検查で, 白血球 $12,900 / \mu \mathrm{L}$, ヘモグロビン $14.0 \mathrm{~g} / \mathrm{dL}$, 血小板 $241,000 / \mu \mathrm{L}, \mathrm{CRP} 9.1 \mathrm{mg} / \mathrm{dL}$ で あった。単純レントゲンで左足関節の軽度の石灰化 を認め, 関節症は軽度であった。

漢方医学的所見：やや小柄であり, 軽度前傾姿勢 であった。舌診では, 淡紅舌で白苔が少なく, 湿潤 であり，歯痕や瘀斑は無かった。舌下静脈の怒張も なかった。脈診は, 浮で大であった。腹診では, 腹 力は中で腹皮拘急があり, 胸脇苦満や腹部の圧痛は なかった。漢方医学的診断としては, 四診では虚実 は中等度以上であり水滞の所見も認められた。血液 検查等で炎症所見があり水滞, 瘀血, 稍強い火熱の 存在が考えられた。

治療経過: 初診当日, 左足関節偽痛風と診断し食 後の内服薬が数種類あり食前に内服する漢方薬を勧 めたところ希望されたため, 越婢加术湯と大黄牡丹 皮湯を併用して $5 \mathrm{~g}$ ずつ分 3 食前 7 日分を投与した。 受診 3 日後の受診時には左足関節痛は軽快したが頚 部痛を認めたため精査することとした。単純レント ゲンで澒椎の中等度の変性を認め, 単純コンピュー ター断層撮影 (computed tomography：CT) で頚椎 軸椎歯突起周辺の石灰化を認めたため, crowned dens syndrome と診断して同処方の内服を継続した。 同日に下痢の訴えはなかった。受診 7 日目には CRP $1.2 \mathrm{mg} / \mathrm{dL}$ と改善した, 前回受診日と次の日にやや 軟便があったと訴えられたが気にならない程度であ り，同処方を 3 日分だけ投与して内服終了とした。

\section{症例 2：（漢方治療有効例）}

患 者: 61歳, 女性。

主 訴: 左肩関節痛

既往歴：40歳時に乳癌で手術を受けた。

現病歴：2 カ月くらい前より左肩痛があるという ことで当院受診した。同疾患にて当院受診前に近医
受診、内服等の医療行為は行っていなかった。

初診時医学的所見：身長 $161.0 \mathrm{~cm}$, 体重 $52.9 \mathrm{~kg}$, 血圧 150/98 mmHg, 脈拍93回/分であった。左肩峰 下滑液包の圧痛在り, 可動域正常であった。単純レ ントゲンで左肩関節の軽度の変性が認められた。

漢方医学的所見：体格は中等度であった。舌診は, 軽度歪斜舌があり, 淡紅舌で, 白苔は少なく茶色で, 瘂斑はなく, 舌下静脈怒張はなかった。脈診は, 浮 で大であった。腹診は, 腹力は中等度で, 臍上悸が あり，腹部の圧痛はなかった。漢方医学的診断とし ては，四診では虚実は中等度以上であるが, 経過や 理学的所見より軽度の炎症所見があり水滞, 疙血, 軽度の火熱の存在が考えられた。

治療経過：左肩関節周囲炎と診断して，ロキソプ ロフェンナトリウム，レバミピドの内服製椷，ロキ ソプロフェンナトリウムのテープ製剤を投与した。

7 日目の再診日に内服により上腹部不快感を認める

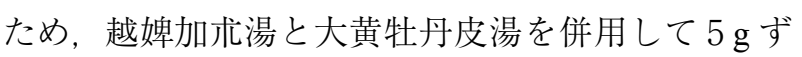
つ分 3 食前 7 日を投与した。15日目の再診時には左 肩関節痛が軽快した，下㾥はなかった，処方の希望 があったため 7 日分投与して終了とした。初診時の 血圧がやや高かったため家庭血圧を記録するよう指 示したところ収縮時血圧が $120 \mathrm{mmHg}$ くらいであり, 高血圧の治療の必要はないと説明した。

症例 3：(漢方治療有効例)

患 者: 90歳女性。

主 訴：腰痛

現病歴：当院にて両変形性膝関節症で治療中であ り, 腰痛があり受診日でもあり当院受診となった。 同疾患にて当院受診前に近医受診, 内服等の医療行 為は行っていなかった。

既往歴：近医にて高血圧と糖尿病でテルミサル夕 ン，テネリグリプチン臭化水素酸塩を内服している。 当院にて両変形性膝関節症で治療中である。当院で 以前に鉄欠乏性貧血で治療をしていたが終了した。

初診時医学的所見：身長 $150.5 \mathrm{~cm}$, 体重 $42.6 \mathrm{~kg}$, 血圧182/98 mmHg, 脈拍78回/分。下肢筋力異常な し, 両腰部圧痛あり。単純レントゲンで腰椎の中等 度の変性と変性側弯があり, 明らかな圧迫骨折はな かった。

漢方医学的所見：やや小柄であった。舌診は, 正 常紅舌であり，無苔でやや乾燥して瘀斑はなかった。 脈診では，沈で細であった。腹診では，腹力は中等 
度で，臍上悸があり，胸脇苦満や圧痛はなかった。 漢方医学的診断としては，四診では虚実は中等度以 上であるが, 理学所見等で軽度から中等度の炎症所 見があり水滞, 瘀血, 軽度の火熱の存在が考えられ た。

治療経過：急性腰痛症と診断した。高齢でもあり 消炎鎮痛剂の副作用も危惧された。また食後の内服 薬が数種類あるため薬剂相互作用を考慮して食前に 内服する漢方薬を勧めたところ希望されたため, 越 婢加尤湯と大黄牡丹皮湯を併用して $5 \mathrm{~g}$ ずつ分 3 食 前 7 日分を投与した。20日後に再来したときの問診 では，前回受診後に屯用で内服してすぐに腰痛が軽 快したという，下痢は認めなかった。希望もあり 2 週間分投与して終了とした。

症例 4：（NSAIDs 投与困難例）

患 者: 83歳, 男性。

主 訴: 左手関節痛

現病歴：秋に柿取りをした，その時に左手を酷使 したという。次の日より左手関節痛があり当日に当 院を受診した。当院を受診以前に本疾患の治療目的 に内服や近医受診を行っていない。

既往歴：近医にて不整脈等に対してリバーロキサ バン, ワーファリンカリウム, フェルビナク貼付薬 を投与されていた。

初診時医学的所見：身長 $165.2 \mathrm{~cm}$, 体重 $60.4 \mathrm{~kg}$, 血圧160/82 mmHg, 脈拍91回/分。初診時左手関節 に高度の発赤腫脹あり, 同部位に圧痛あり, 血液検 査上, 白血球 $9,000 / \mu \mathrm{L}$, モグロビン $13.6 \mathrm{~g} / \mathrm{dL}$, 血小板 $172,000 / \mathrm{dL}$, 尿酸 $4.4 \mathrm{mg} / \mathrm{dL}, \mathrm{CRP} 13.5 \mathrm{mg} /$ $\mathrm{dL}$ であった。単純レントゲンで左手関節に石灰化 を認め, 偽痛風による左手関節の関節炎と診断した。

漢方医学的所見：体格は普通であった，舌診では 稍紅で舌裂紋あり白苔無し瘀斑なし舌下静脈の怒張 が軽度あった。脈診は浮で大であった。腹診では腹 力中で胸脇苦満あった。漢方医学的診断としては, 四診では虚実は中等度以上であり疙血の所見もあっ た，理学所見で関節炎の腫脹もあり水滞，火熱が考 えられ, 血液検查等で強い炎症所見があり水滞, 疙 血，強い悠の存在が考えられた。

治療経過：偽痛風と診断し, NSAIDs の使用を検 討したがワーファリンを投与されており NSAIDsの 使用が困難であると判断して越婢加尤湯と大黄牡丹 皮湯を併用して $5 \mathrm{~g}$ ずつ分 3 食前 7 日分を投与した。
炎症が強いため，2 日後に再診とした。再診日には 疼痛が稍軽快して, 血液検査上 CRP $8.2 \mathrm{mg} / \mathrm{dL}$ と 低下した。7 日後には疼痛が消失し, 手関節の腫脹 も消失して, 圧痛も無くなり CRP $0.5 \mathrm{mg} / \mathrm{dL}$ と改 善したため治癒と判断した。下痢は認めなかった。

症例 5：（NSAIDs 投与困難例）

患 者：38歳, 女性。

主 訴: 腰痛

現病歴: かごを持ち上げて腰痛があり, 同日当院 を受診した。当院を受診以前に本疾患の治療目的に 内服や近医受診を行っていなかった。9 月月前に出 産をしており，授乳中であった。

初診時医学的所見: 身長 $155 \mathrm{~cm}$, 体重 $49.6 \mathrm{~kg}$, 血圧106/61 mmHg, 脈拍75回/分。歩行にて疼痛が あり, 院内では歩行器で移動していた, 明らかな腰 部, 坐骨神経等の圧痛は無かった。単純レントゲン で腰椎の軽度の変性のみ認めた。

漢方医学的所見：やや小柄であり, 舌診では淡紅 舌で白苔が少なく軽度胖大であるが歯痕はなく瘂斑 なく舌下静脈の怒張は無かった。脈診では浮で細で あった。腹診では腹力が中等度であった。下腿の浮 腫は無かった。漢方医学的診断としては, 四診では 虚実は中等度以上であり水滞の所見もあった, 理学 所見等で軽度から中等度の炎症所見があり水滞, 疙 血, 軽度の火熱の存在が考えられた。

治療経過: 急性腰痛症と診断したが, 授乳中のた め NSAIDs の投与を希望せず漢方薬であれば内服す るということで, 越婢加术湯と大黄牡丹皮湯を併用 して $5 \mathrm{~g}$ ずつ分 3 食前 7 日分を投与した。次の日か らつかまり歩きが楽に出来るようになり，2 日目か ら手放しで歩行できるようになり急激に疼痛が改善 したため初診時の投薬分で終了とした。便通はよく なったが下痢は無かった。

\section{症例 6：(NSAIDs 無効例)}

患 者：43歳, 男性。

主 訴: 左手関節痛

現病歴：左手関節痛が外傷などの誘因無く起こり， 自己判断で市販のイブプロフェン配合薬を内服した が軽快せず，次の日に当院を受診した。

初診時医学的所見：身長 $168 \mathrm{~cm}$, 体重 $75.6 \mathrm{~kg}$, 血圧155/105，68で，左手関節痛あり，TFCC 部に 圧痛あり手背の腫脹あり。単純レントゲンで左手関 節の軽度の関節症を認め, 石灰化無は認めなかった。 
血液検査上, 白血球 $6,700 / \mu \mathrm{L}$ ，へモグロビン $14.4 \mathrm{~g}$ $/ \mathrm{dL}$ ，血小板 $145,000 / \mathrm{dL}$ ，尿酸 $7.3 \mathrm{mg} / \mathrm{dL} ， \mathrm{CRP} 3.1$ $\mathrm{mg} / \mathrm{dL}$ であった。炎症所見を認め尿酸值が稍上昇 しているため痛風と診断した。胃潰瘍等の既往もな いため，ロキソプロフェンナトリウム，レバミピド の内服，ロキソプロフェンナトリウムの外用薬を投 与したが疼痛が改善せず 2 週間後再診となる。

漢方医学的所見：体格は中肉中背で左手関節痛あ り，不眠無し，心煩無し，咳なし，二便の異常なし， 手足の火照り等無し。舌診では淡紅舌で白苔少なく 歯痕あり瘀斑なし。脈診では浮で大であった。腹力 中で胸脇苦満や圧痛は認めなかった。両下腿に浮腫 が軽度あり。漢方医学的診断としては, 四診では虚 実は中等度以上であり水滞の所見も認められた，血 液検査等で中等度の炎症所見があり水滞, 疮血, 中 等度の火熱の存在が考えられた。

治療経過：同日より越婢加术湯と大黄牡丹皮湯を 併用して $5 \mathrm{~g}$ ずつ分 3 食前 7 日分を投与した。 8 日 後の再診時には左手関節痛が軽快して同部位の圧痛 が軽快した。下痢は無く便の回数も変わらず, 症状 が軽快して治癒と診断した。

\section{考察}

すでに，筆者は越婢加术湯と大黄牡丹皮湯の併用 による方剂を使用し crowned dens syndromeに対す る症例報告を行っている11。最近では整形外科疾患 の様々な疾患に対して多数の治療を行っており有効 性を確認している。今回, 代表症例を提示し同処方 の方意や古典的考察を行った。つぎに, NSAIDs が 使用困難または無効例に対して同処方が有効であっ た代表症例を提示してそれぞれに対する考察を行っ た。

\section{(1) 古典的考察}

古典では四肢の疼痛について様々な用語が使用さ れており，『雑病源流犀燭』（沈金鰲，1773年）の諸 痺源流には, “白虎歴節風は痛痺の 1 つの症状であ る。その痛みが全身を動くので歴節という。その痛 みは虎が咬むくらい甚だしく白虎歴節という。(『雑 病源流犀燭』巻十三 諸瘏源流）〔原文 1〕”とあり， 痺症，痛痺，歴節，白虎歴節の用語が記載されてい る。中尾らは古典における関節の腫脹や疼痛に関す る用語を調査して, 中風歴節, 歴節風, 白虎, 白虎 風, 白虎歴節，白虎歴節風，白虎歴節風痛瘏，痛風， 鶴膝風, 脚気, 走注, 痺症の12種類を挙げており
様々な用語が使用されている2)。これらは痛風, 変 形性関節炎関節リウマチ，痛風，偽痛風，变形性関 節症等の疾患を包含した虚実様々な整形外科領域の 広範囲の疼痛性疾患をまとめて治療対象にしている とも考えられる ${ }^{344}$ 。

今回, 整形外科領域の疼痛性疾患に対して越婢加 术湯と大黄牡丹皮湯を併用して使用した。痛風に対 して大黄牡丹皮湯を用いる報告はあり, 板東は,「痛 風の発作時で関節に疼痛, 腫脹があるときに大黄牡 丹皮湯合麻杏甘石湯が有効である。組成としては, 桃仁，牡丹皮，冬瓜子，大黄，芒硝，麻黄，杏仁， 甘草, 石亳である。麻黄と石亳が消炎解熱, 利尿作 用で滲出性炎症を治療し, 大黄, 牡丹皮, 冬瓜子で 消炎作用があり，桃仁，牡丹皮で化瘀止痛作用があ り，血腫，内出血など㾋血を吸収して痛みを止める， 大黄, 芒硝で瀉下作用があり, 分解吸収した血腫を 瀉下して排出する, 麻黄, 石膏, 杏仁, 冬瓜子で利 水作用により浮腫を除き, 身体各所の関節の炎症, 疼痛, 腫脹に用いられる。」と述べている5)。またそ の中で, 大黄牡丹皮湯合麻杏甘石湯は麻黄赤莐湯『医 学入門』(李梴, 1575年) と霊仙除痛湯『万病回春』

（襲廷賢，1587年）が近似の方剤であると指摘して いる ${ }^{5)}$ 。今回使用した越婢加术湯と大黄牡丹皮湯の 併用の方意も上記の大黄牡丹皮湯合麻杏甘石湯と同 様に利水，化㾉で止痛作用があり類似しており，身 体各所の関節の炎症，疼痛，腫脹に対して有効であ ると考えている。本処方は上記の大黄牡丹皮湯合麻 杏甘石湯に比べて大雵と蒼术が加味されているため, 健脾益気，宣肺利水作用がより強化されおり，ょり 有効であると考えられる。今回，副作用については 上部消化管症状等の発症もなく, 麻黄が含まれてい るが血圧上昇等の副作用もなかった。症例 1 に軟便 を認めたが，軟便や下㾥は副作用ではなく効果の現 れである。大黄で腸中の熱毒を瀉下して清熱涼血に 働き6)，止痛の効果を得るため副作用ではないと考 える。このことは投与時に患者に対する十分な説明 が必要である。

上述の板東が引用した麻黄赤药湯『医学入門』の 組成は麻黄，赤药，防風，荊芥，姜活，独活，白芷， 蒼术, 威霊仙, 葛根, 升麻, 黄芩, 枳実, 桔梗, 当 帰，川芦，甘草であるとしているが5)，大黄牡丹皮 湯の君薬である大黄が含まれていない( ${ }^{6)}$ 。出典とさ れる『医学入門』には, “麻黄赤药湯 麻黄・赤药 
各一銭, 防風 - 荊芥 - 姜活 - 独活 - 白芷 - 蒼术 - 威

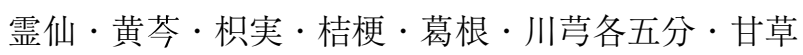
·当帰・升麻各三分, 下焦には酒柏を加え, 婦人に は酒炒した紅花を加え, 腫脹があれば檳榔・沢瀉を 加え, 痛みには乳香, 没薬, 疙血には桃仁・大黄を 加える。煎じて内服する。湿熱が肢節に流注して腫 痛する者を治療する（医学入門・巻之六・雑病用薬 賦・風）〔原文 2 〕”とあり, ここでは麻黄赤药湯 に瘀血の症例に対して桃仁・大黄を加味するとして いる。また，『万病回春』の霊仙除痛飲も同一の処 方であり ${ }^{9)}$, 『雑病源流犀燭』では霊仙除痛飲の別名 が麻黄赤药湯である事を指摘している ${ }^{10)}$ 。

本処方と類似した処方について, 板東は「大黄牡 丹皮湯合麻杏甘石湯について, 麻黄赤药湯とよく似 た方意であり，同じような目的で身体各所の関節の 炎症, 疼痛, 腫脹に用いられる」5), としている。我々 も同様に越婢加术湯と大黄牡丹皮湯の併用の適応で きる疾患は多くの炎症を伴った整形外科領域の様々 な疾患に適応があると考えている。痛風, 偽痛風に 限らず整形外科の多くの疼痛性疾患は臨床的に程度 の差はあるが，腫脹，発赤，発熱を主徵とする関節 炎症状を特徵とする7)。西洋医学的には, 炎症の 5 徵は腫脹, 発赤, 発熱, 疼痛, 機能不全であり ${ }^{8)}$, まず腫脹, 発赤, 発熱が抗こり, 結果として疼痛, 機能不全が起こると考えられる。前述の『万病回春』 の霊仙除痛飲の記載の中にも,「痛みは火に属し, 腫れは湿に属す」9), とあり西洋医学的な炎症の考元 方と一致する。炎症の漢方医学的な弁証では水滞, 痁血，火熱が生じていると考えられ，治法としては 利水，活血化瘀，清熱して止痛を行うべきである。 使用した方剂としては利水, 清熱の越婢加术湯を使 用し，清熱を補う方剂として活血化疼清熱の作用が 強い大黄牡丹皮湯を併用することで除痛を行い，整 形外科疾患全般に対して有効であると考えており， 西洋医学的にも東洋医学的にも非常に理のかなった 処方と考えられる。

(2) NSAIDs 使用困難または無効例に対する漢方 治療について

ワーファリンの内服中や，授乳中であり NSAIDs が困難な症例や，NSAIDs が無効な症例に対して同 処方を投与して有効であったので各症例について文 献的考察を行う。

症例 4 の偽痛風の症例はワーファリン内服中であ
る。例えば広く使われている NSAIDs のロキソプロ フェンは相互作用としてワーファリンの作用を増強 する可能性があり ${ }^{11)}$, 使用が困難である。これは, 血漿中蛋白への結合が, 併用薬と競合することに よって起こる変動であり, NSAIDsは血漿中アルブ ミンへの親和性が強くワーファリンと併用したがあ り両薬物の血漿中遊離型濃度を上昇させ, 両薬物の 副作用を引き起こす可能性が有るため併用注意であ る ${ }^{12)}$ 。しかし本症例は偽痛風による左手関節炎で $\mathrm{CRP} 13.5 \mathrm{mg} / \mathrm{dL}$ と上昇しており局所の発赤腫脹が あり積極的な治療が望まれたため, 越婢加术湯と大 黄牡丹皮湯の併用による方剂を投与して約一週間で 疼痛や発赤腫脹が消失して CRP もほぼ正常まで低 下した。ワーファリンと漢方薬の相互作用について は丹参, 当帰, 朝鮮人参, イチョウ葉エキス等がワー ファリンの作用を増強するといった報告があるが, 葛根湯，小柴胡湯，補中益気湯等の方剂はワーファ リンの作用に影響が無いという基礎的研究も多数あ り ${ }^{13)}$ ，ワーファリンと越婢加术湯と大黄牡丹皮湯併 用による方剤についての報告は渉猟し得なかったが， 相互作用は臨床上で問題ないと考えられる。

症例 5 は授乳中に急性腰痛症を発症した症例であ る。初診時に院内で歩行器を要するほど疼痛が強 かったため積極的な治療が望まれた。しかし授乳中 であり NSAIDs 等の西洋薬を希望されなかった。授 乳中の投薬について, 代表的な NSAIDsであるロキ ソニン ${ }^{\circledR}$ (第一三共）の添付文書には，「授乳中の婦 人に投与することを避け，やむを得ず投与する場合 には授乳を中止させること。」とあり ${ }^{14)}$ ，文面から は投与禁忌と考えられる。今回使用した漢方製剤は 越婢加尤湯と大黄牡丹皮湯であり, 後山は大黄には アントラキノン誘導体を含むため新生児下痢を誘発 し，エフェドリンを含むため新生児に光奮ほてりを 誘発する。麻黄には塩酸エフェドリンが主成分であ るため新生児にほてりを誘発するため慎重に投与し， 麻黄剤同士の併用, MAO 阻害剤, 甲状腺ホルモン 製剂，カテコールアミン製剤，キサンチン系製片と の併用は避けるべきとしている ${ }^{15)}$ 。しかし, 製薬会 社の添付文書には授乳婦への投与では越婢加尤湯に 含有する麻黄の注意は指摘しておらず，大黄牡丹皮 湯に含有する大黄の注意として授乳中の婦人には慎 重に投与することとしている ${ }^{16)}$ 。慎重に投与という のは，具体的には母乳を投与した直後に薬剤を内服 
したり，乳児が長時間の睡眠に入る直前に服用する ことによって乳児の薬哓への暴露を最小限にする ${ }^{17)}$ 。 また，乳児が下痢をしていないか，興奮して入眠が 困難になっていないかを観察させるよう指導すると いったことである。また，越婢加术湯の麻黄につい て心配であれば調栄活絡湯の方意として大黄牡丹皮 湯と四物湯の併用が有用である ${ }^{18)}$ 。また，母乳を介 した薬剤の新生児全摂取量は母体の通常 $1 \%$ 以下に なると考えられており ${ }^{17}$, 過度に心配するあまり母 体の健康を損なうことがないようにすべきである。 古代以来妊娠中の生薬の摂取についての記載は存在 しており，『神農本草経』にも6 生薬に堕胎の作用 があると記載されており ${ }^{19)}$, 妊娠時服薬禁忌薬と捉 えることができる。現在の日本の薬剤の添付文書に は授乳時の内服について「授乳を避けさせる」「授 乳を中止させる」「授乳をさせない」等と述べられ

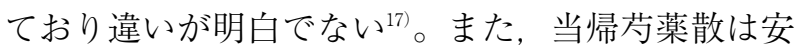
泰薬として用いられ ${ }^{15}$, 現在の製薬会社の添付文書 の効能にも「妊娠中の諸病」とあるが20), 同書中に 「妊娠中の投与に関する安全性は確立していないの で，妊娠または妊娠している可能性のある婦人には， 治療上の有益性が危険性を上回ると判断される場合 にのみ投与すること。」とあり ${ }^{16)}$, 効能と矛盾して いる。結果的に薬剤の使用責任は現場に委ねられて いるといった情況が継続していると考えられる。

症例 6 は痛風発作に対して NSAIDs が無効であっ た。具体的な処方内容としては市販のイブプロフェ ン配合薬とロキソプロフェンナトリウムが無効で あった。西洋医学的治療で痛風発作のガイドライン に沿った治療をするのであればインドメタシンの投 与やナプロキセンのパルス療法を行う ${ }^{21}$ 。今回は消 化管への負担がより少ないと考えられる越婢加术湯 と大黄牡丹皮湯併用による方剂を投与して有効で あった。痛風等の疼痛性疾患に於いて, プロスタグ ランジン（prostaglandin：PG）の関与する疼痛は, 侵害受容性疼痛に分類される, 侵害受容性疼痛では, 炎症性刺激や組織損傷などによって肥満細胞や血管 系組織などから産生される $\mathrm{PG}$, ブラジキニン, ヒ スタミン，セロトニン，及びサブスタンス $\mathrm{P}$ 等の いわゆる疼痛物質がシグナル伝達物質として作用し ている。これらの物質が侵害受容神経線維の侵害受 容器に結合し, 痛みとして大脳知覚領域へと信号が 伝わる22)。これに対して, NSAIDsの主たる作用機
序は, シクロオキシゲナーゼ (cyclooxygenase : COX) 阻害による, PG 類産生抑制であり ${ }^{22}$, 侵害 受容性疼痛に対して有効である。それに比べて, 越 婢加术湯と大黄牡丹皮湯の作用については, 越婢加 术湯の構成生薬である麻黄に石膏を用いることで抗 炎症作用が増強されて利水に働き浮腫や腫脹に効果 があり, 麻黄に蒼术を用いて関節や筋肉の疼痛や浮 腫に効果がある ${ }^{23)}$ 。それに大黄牡丹皮湯の構成生薬 である大黄に駆㾋血薬の牡丹皮と桃仁を加えて相乗 効果で強い疗血作用を発揮して炎症を伴う瘀血に効 果があり，冬瓜子には清熱消炎と排膿作用がある ${ }^{24}$ 。 このようにして現在起こっている炎症に対して漢方 医学的なアプローチを用いて NSAIDsでは押さえき れなかった炎症や疼痛に効果があったと考えられた。 また, NSAIDs と漢方薬の効果の比較についての報 告があり, 変形性膝関節症に対して比較的抗炎症作 用が弱い NSAIDs を中心として投与して, 漢方薬の 随証治療と比較して漢方薬の方に効果があったとし ている ${ }^{25)}$, 漢方薬は証が合えば NSAIDsよりも有効 であることが示されている。本症例では, 市販のイ ブプロフェン配合薬とロキソプロフェンナトリウム が無効であり，比較的抗炎症作用の強いロキソプロ フェンナトリウムよりも抗炎症作用を有すると考え ている，この事は症例 4 にも示した通りかなり炎症 の強い症例にも有効であったことからも確認できる。

自験例では今回提示した 3 症例の, ワーファリン の内服中や授乳中で NSAIDs が使用できない症例や NSAIDs が無効な症例の他にも症例はある。その他 の症例としては, 以前より胃が弱いという症例, 胃 潰瘍の既往のある症例, 喘息の治療中などで NSAIDs の使用が困難な症例, NSAIDsによる薬物 乱用性頭痛の既往のある症例, 多剤を食後に内服し ている症例で薬物相互作用として効果の増強や減弱 が起こる可能性もあり ${ }^{26)}$, これらに対して越婢加术 湯と大黄牡丹皮湯の併用を食前に投与して有効で あった。整形外科領域の様々な疾患に対して本処方 は有効であり，様々な理由で NSAIDs を使用できな い症例や無効例に対しては特に有効な治療法であっ た, 漢方治療は整形外科の診療には必要不可欠であ ると言える。

\section{結論}

1. 越婢加术湯と大黄牡丹皮湯の併用は, 『万病 回春』の霊仙除痛湯, 『医学入門』の麻黄赤䓎 
湯の方意が近似の方片である。

2. 整形外科領域の多くの, 従来では NSAIDs を 使用していた炎症を伴った疼痛性疾患に対して 越婢加术湯と大黄牡丹皮湯の併用が有効である。

3. 諸般の事情でNSAIDs を使用できないまたは 無効な症例に対して越婢加术湯と大黄牡丹皮湯 の併用が有効であった。

附記 本報告で用いた越婢加尤湯は, ツムラ越婢加 术湯（医療用）であり， $7.5 \mathrm{~g}$ 中に石膏 $8.0 \mathrm{~g}$, 麻黄 6.0 $\mathrm{g}$, 蒼术 $4.0 \mathrm{~g}$, 大霖 $3.0 \mathrm{~g}$, 甘草 $2.0 \mathrm{~g}$, 生姜 $1.0 \mathrm{~g}$ の割 合の混合生薬の乾燥エキス $3.25 \mathrm{~g}$ を含有する。

本症例で用いた大黄牡丹皮湯は, ッムラ大黄牡丹皮 湯（医療用）であり，7.5 g 中に冬瓜子 $6.0 \mathrm{~g}$, 桃仁 4.0 $\mathrm{g}$, 牡丹皮 $4.0 \mathrm{~g}$, 大黄 $2.0 \mathrm{~g}$, 無水芒硝 $1.8 \mathrm{~g}$ の割合の 混合生薬の乾燥エキス $3.5 \mathrm{~g}$ を含有する。

上記をツムラ越婢加术湯（医療用） $5.0 \mathrm{~g}$, ツムラ 大黄牡丹皮湯（医療用） $5.0 \mathrm{~g}$ を分 3 食前に投与した。

〔原文 1〕“白虎历节风 痛㿎之一证也。以其痛循 历遍身百节, 故曰历节。以其痛甚如虎咬, 故曰白虎 历节。(『杂病源流犀烛』巻十三 诸痹源流 $)^{27}$

〔原文 2〕 “麻黄赤药汤 麻黄, 赤药各一钱, 防风, 荊芥, 姜活, 独活, 白芷, 苍术, 威灵仙, 片芩, 枳 实, 桔梗, 葛根, 川芦各五分, 甘草, 归尾, 升麻各 三分。下焦加酒粕, 妇人加酒炒红花, 肿多加槟榔, 泽泻, 痛加乳, 没, 疼血加桃仁, 大黄。水煎服。治 湿热流注, 肢节肿痛。(医学入门·巻之六·杂病用 药賦·风” 28)

利益相反（COI）に関して開示すべきものなし。

\section{文献}

1) 福嶋裕造, 井藤久雄, 田頭秀悟, 他. 漢方薬が著効し た crowned dens syndromeの 1 例。日東医誌 2017 ; $68: 372-376$.

2 ) 中尾紀久世, 森山健三, 村田和也, 他. 現代の痛風 （Gout）の関節痛に用いる漢方処方と生薬の来歴. 薬 史学雑誌 $2011 ； 46 ： 91-101$.

3 ) 陳有昭. 中国医学辞典. たにぐち書店, 東京 2010. 596.

4 ）陳有昭. 中国医学辞典. たにぐち書店, 東京 2010. 713.

5 ）板東正造. 病名漢方治療の実際. メデイカルユーコン, 京都 2009.251-252。
6 ）芦田延之, 芦田正毅, 伊賀文彦, 他. 中医臨床のため の方剂学. 東洋学術出版社, 千葉 2012. 578-579.

7 ) 飯島宗一, 景山圭三, 石川栄世, 他. 組織病理アトラ 又. 文光堂, 東京 1988. 409.

8 ）矢田純一, 高橋秀実, 東みゆき, 他. イラストレイ テッド免疫学. 丸善出版, 東京 2009. 56.

9 ) 龔廷賢. 万病回春 中医臨床必読叢書. 人民衛生出版 社, 北京 2007. 307-308.

10）沈金鰲. 杂隹病源流犀燭 中医臨床必読叢書. 人民衛生 出版社, 北京 2006. 397.

11）青崎雅彦, 岩出和徳, 越前宏俊. Warfarin 適正使用情 報、第 3 版, エーザイ株式会社, 東京 2017. 314 .

12）榎園淳一. タンパク結合評価. 日薬理誌 $2009 ； 134$ : $78-81$.

13）青崎雅彦, 岩出和徳, 越前宏俊. Warfarin 適正使用情 報、第 3 版，エーザイ株式会社，東京 2017．639-640.

14）添付文書, 第一三共：https ://www.medicallibrary-dsc. info/di/loxonin_tablets_60 mg/pdf/pi_lox 4_1603_19.pdf\# search $=\%$ 27第一三共+ロキソニン＋添付文書 $\% 27$, (参照2017-11-25).

15）後山尚久. 周産期医療と漢方. 産婦人科の進歩 $2003 ; 55: 299-321$.

16）株式会社ツムラ。ツムラ医療用漢方製剤。東京 2015 . 49-50.

17）三鴨廣繁. 特殊病態における抗菌化学療法 4. 妊婦. 日内会誌 $2008 ； 95 ： 2208-2213$.

18）福嶋裕造, 井藤久雄, 田頭秀悟, 他. 急性腰痛症に対 して大黄牡丹皮湯と四物湯の併用が著効した治療経験. 日東医誌 $2018 ； 69 ： 35-41$.

19）勝田正泰. “妊娠服薬禁忌歌” の検討. 日東洋医会誌 $1981 ; 31: 239-244$.

20）株式会社ツムラ。ツムラ医療用漢方製荗。東京 2015. 93-94.

21）山中寿, 上田孝典, 大野岩男, 他. 高尿酸血症 - 痛風 の治療ガイドライン第 2 版 2012年追補ダイジェスト 版.メディカルレビュー社, 大阪 2012. 9.

22）楠夏子, 川合眞一. NSAIDs と DDS. Drug Delivery System $2011 ; 26: 468-475$.

23）岡村信幸. 漢方薬物解析学. 廣川書店, 東京 2005 . 169.

24）岡村信幸. 漢方薬物解析学. 廣川書店, 東京 2005 . 151.

25）堤哲也，大竹哲也，石倉秀昭. 変形性関節症に対する NSAIDs と漢方薬の鎮痛効果の比較. 日本ペインクリ ニック学会 $1997 ； 4: 19-22$.

26）石崎高志. 多薬投与時の相互作用. 日内会誌 1992 ; 81:266-273.

27）沈金鰲. 杂病源流犀燭 中医臨床必読叢書. 人民衛生 出版社, 北京 2006. 392 .

28）李梃. 臨床各科巻 - 総合 (四) 医学入門 中医臨床必読 叢書合訂本．人民衛生出版社，北京 2011. 770.

29）竟廷賢. 万病回春 中医臨床必読叢書. 人民衛生出版 社, 北京 2007. 307. 